\title{
The Diversity of Responsibility: The Value of Explication and Pluralization
}

\author{
Silke Schicktanz $•$ Mark Schweda
}

Received: 15 August 2011/Accepted: 20 October 2011/Published online: 6 December 2011

(C) The Author(s) 2011. This article is published with open access at Springerlink.com

\begin{abstract}
Purpose Although the term "responsibility" plays a central role in bioethics and public health, its meaning and implications are often unclear. This paper defends the importance of a more systematic conception of responsibility to improve moral philosophical as well as descriptive analysis.

Methods We start with a formal analysis of the relational conception of responsibility and its metaethical presuppositions. In a brief historical overview, we compare global-collective, professional, personal, and social responsibility. The value of our analytical matrix is illustrated by sorting out the plurality of responsibility models in three cases (organ transplantation, advance directives, and genetic testing).

Results Responsibility is a relational term involving at least seven relata. The analysis of the relata allows distinguishing between individual versus collective agency, retrospective versus prospective direction, and liability versus power relations. Various bioethical ambiguities result from insufficient, implicit, or inappropriate ascriptions of responsibility.

Conclusions A systematic conception of responsibility is an important tool for bioethical reflection. It allows an in-depth understanding and critique of moral
\end{abstract}

S. Schicktanz $(\bowtie) \cdot$ M. Schweda

Department of Medical Ethics and History of Medicine, University Medical Center Göttingen, Humboldtallee 36, 37073 Göttingen, Germany

e-mail: silke.schicktanz@medizin.uni-goettingen.de claims on a meta-ethical level without presuming one particular normative approach. Considering the concept of responsibility can also help to complement the current bioethical focus on individual autonomy by including the perspectives of other actors, such as family members or social groups.

Keywords Responsibility - Applied ethics .

Bioethics · Conception · History · Organ transplantation · Advance directives - Genetic testing · Personal versus social responsibility $\cdot$ Professional responsibility

\section{Introduction}

The term "responsibility" has become an integral but diverse element of bioethical and public health debates. Thus, the promotion of responsible health behavior constitutes a major effort of health care policies in Europe and the United States. In the name of "personal responsibility for health," the US health care reform proposes "cost-sharing options" that are supposed to "reflect mainstream thinking" (Center for Medicare and Medicaid Services 2006: 4). Furthermore, there are heated debates about the responsibility of the physician, for instance in the case of assisted suicide. Recently, the German Medical Association declared in its revised guidelines on end-of-life 
treatment that assisted suicide "is not a medical task" (Bundesärztekammer 2011: 346)—but there still exists the physician's "own responsibility in a concrete situation" (ibid.). A third example is the UNESCO Declaration of Bioethics and Human Rights. It states a "social responsibility" of societies and governments regarding the "promotion of health and social development for their people" (UNESCO 2005: Article 14).

These examples elucidate that "responsibility" is a term in bioethics that appears everywhere-and at the same time nowhere. No term has such an elusive role and multiple meaning. This might be a reason for some scholars to avoid its systematic use and not invest much normative scrutiny. One of the most common conceptions in applied medical ethics, the principlist approach developed by Tom Beauchamp and James Childress (2009), provides an excellent example. The whole work has no particular chapter or paragraph dealing with responsibility as a normative principle or framework. Likewise, the Encyclopedia of Applied Ethics (Callahan et al. 1997), another standard work in medical ethics, lacks an entry on responsibility.

This lacuna points to a serious problem: "Responsibility" is a key term in so many contexts related to medicine, health care, and biotechnology that we cannot afford to ignore or delude its meaning. Despite the broad use of "responsibility" in empirical practice, assuming that it is mainly a "practical" concept would neglect its important theoretical dimension and tradition. However, rather than of offering one single model of responsibility as a substantial normative solution for all bioethical problems, we suggest to deal with responsibilities (in plural). This means that there are different models of responsibility, each of them appropriate in particular contexts. Thus, instead of dismissing "responsibility" as a "term non grata" for bioethics, we consider its relational composition as well as the plurality in models of responsibility to have an important analytical value for ethical reflection. By acknowledging "responsibility" as a leading concept for applied ethics, a more concrete approach and more social relevance will be gained and the individual dimension of the doctor-patient relationship can easily be linked to the institutional as well as societal level and the public health dimension.

By pursuing this line of argument, we aim at the following: First, we provide a formal classification of various conceptions of responsibility, given that there exists a lot of unsystematic or even rhetorical use of the word. We use the term "conception" to refer to formal, general ideas. This summary is based on a systematic analysis of different theoretical and applied works in philosophy and includes an analysis of conditions as well as of contexts of application. We explain how "responsibility" as a normative concept is - on a meta-ethical level-distinguished from and at the same time related to other formal ethical principles, such as autonomy, justice, or non-maleficence. Secondly, we analyze the use of different models of responsibility in bioethics in a descriptive perspective. With models, we refer to particular explanations and specific contexts. We identify three stages of the use of responsibility within Western bioethics since the late 1960s. These stages are based on the following: a holistic model of global responsibility, a model of professional responsibility, and a model that focuses on the relation between the individual and the community. We do not argue for one particular model, but for the normative importance of an explication and differentiation of models, preserving their diversity. The juxtaposition of these models allows us to detect moral problems related to power relations and normative inconsistencies and to analyze limitations and one-sided usage of specific models. In this sense, the ethical consideration of responsibility can overcome limits of other common approaches in applied ethics. Finally, we illustrate our theoretical considerations with regard to different fields of application. We demonstrate the hermeneutic value of such a broader understanding of responsibility and show how ethical analysis can benefit from taking different models into account- those which are stated explicitly, and those which are implicit or still neglected. Once one has accepted that there are different possible models, a discussion on the underlying subjects, norms, instances, and normative consequences has to start.

\section{Formal Analysis of Responsibility in Its Diversity}

The following analysis divides into three dimensions: First, the basic normative structure of all responsibility models is disentangled by introducing a general concept. This concept is a relational one: It is described in a formula comprising a set of relations between different positions (relata). Second, the 
conditions and normative presumptions of the relata are analyzed. Third, the fact is considered that different norms and instances used as relata imply different moral presuppositions and commitments.

\section{The Structure of Responsibility: A Relational} Concept of Moral Agency

In philosophy, various authors have made attempts to develop a typology of responsibility (e.g., Baier 1991; French 1991a, b, c, d; Ropohl 1996). Moreover, the dominant use of the term in the legal sphere has shaped all attempts to differentiate types of responsibility (Holl et al. 2001; Bayertz 1995; see also Hart 1968). ${ }^{1}$ Thus, "responsibility" still is often used in the sense of "being blameworthy" or "being guilty."

However, the explanation itself provides an important hint at the formal structure of responsibility: In the legal context, it means a person is answerable-the person has to respond to accusations raised in front of a court or in parliament (Holl et al. 2001). Already in this context, responsibility turns out to be a relational concept: A person is being held responsible by a court/ authority regarding the blameworthy outcomes of his or her actions and must await a judgment that implies legal or social consequences. In other contexts, positive outcomes and rewards can occur, too.

With this formal conception, we refer to an analytical, meta-ethical understanding, but not to a particular normative approach of responsibility. This general conception explicitly denotes a relation between several entities. At least, the concept of responsibility requires three relata, a subject, an object, and an instance: Someone (the subject, as we will argue the moral agent) is responsible for someone or something (the object) against someone (the instance). However, on closer inspection, it turns out that more-five, six, or even seven-relata are necessary to reconstruct and analyze the use of the concept responsibility in an adequate manner (Werner 2002). For the subsequent analysis of the role of responsibility in the bioethical debate, we suggest a conception involving seven relata:

\footnotetext{
${ }^{1}$ Peter French refers to Aristotle as the classical founder of our current use of responsibility, especially with regard to the question under which conditions of knowledge, choice, and free will one counts as a morally responsible person (see extracts of Aristotle in: French 1991a: 24-38).
}

Someone (subject) is in a particular time frame (time) retrospectively/prospectively (temporal direction) responsible for something/someone (object) against someone (norm-proofing instance) on the basis of certain normative standards (standard) with certain sanctions or rewards (consequences).

We argue that this seven-relata formula covers the most important normative aspects of different models of responsibility in the bioethical context. In particular contexts, more relata can be useful. With regard to this relational conception, the relata can be interpreted as variables: One can theoretically fill in the different categories with a particular, possibly infinite number of items. The number of possible relations in the model is vast; they can be expressed by the formula $(n=$ number of items): $n(A) * n(B) * n(C) * n(D) *$ $n(E)$.

With regard to the explanation of this formula, the temporal direction and distinction between retrospective/prospective is fundamental for the understanding of responsibility. In the legal context, responsibility is primarily discussed in a retrospective (backward) perspective. The concept of guilt is used to ascribe a certain course of harmful past events to a particular person who can be identified as their author. This retrospective concept is therefore also called causal responsibility (Bayertz 1995: 119; French 1991c: 113) or liability model (Young 2011: 97).

In the rise of modern society, however, a second, prospective meaning became prominent (Bayertz 1995). According to this meaning, having responsibility for an object, a person, or a group means being in charge of or taking care of future events. Prospective (future- or forward-oriented) responsibility became important in the context of modern functional differentiation and work division which led to an increasingly complex network of social roles and functions. Furthermore, technological progress made the consequences of decisions ever harder to anticipate (e.g., by the decoupling of place, time, and effects, see Strydom 1999; Bayertz 1995). Responsibility is therefore associated with competence and/or power to decide (ibid.). With this temporal shift, the whole normative meaning changes (Young 2011: 76-93). Prospective responsibility is also important in the political-philosophical context. It allows expressions and justifications of socio-political engagements as a forwardoriented model of taking responsibility (ibid. 89). 
The assignment of some items is quite disputable. Some are object to controversy with regard to moral status, moral commitment, and justification of norms (see below). When it comes to bioethics, some items are more accepted, or at least more common, than others. So with regard to the category subject, all items that can be seen as moral agents are useful. Note that agency includes active performance of actions as well as omissions (e.g., omitting of help for a person in a life-threatening case) (Feinberg 1991; Held 1991).

Of course, in everyday language we also tend to say "The virus is responsible for the infection" or "alcohol is responsible for hepatic damage." However, this way, the ideas of causality and responsibility are confounded. While causality is an important part of responsibility-assignments and judgments, it is problematic to equalize both in the moral context. There is consensus that any moral meaning of responsibility can only be assigned to moral agents (Yoder 2002: 24). Between different moral theories exists, however, dissent about whether only persons or also collectives (e.g., families, states/nations, political groups, random groups, companies) can be classified as moral agents (see below).

With regard to the category objects, all moral agents can be seen as moral objects, but there can be even more entities. For example, in bioethics, we discuss whether human embryos, brain-dead patients, next generations, animals, plants, or nature as a whole (Warren 2000) can be according to their moral status and underlying anthropologies considered as objects of responsibility. The relatum object also includes subaspects of moral objects, such as the health or body of a person, or entities understood as property of a moral agent (e.g., the donated organ).

With regard to the category instance, we already saw that the court (or similar legal authorities) is a wellaccepted instance. But in moral terms, we can (and must) think of other authorities, as well, such as social peer groups, individual conscience, or God. An instance obviously has a norm-proofing (and even norm-enforcing) function. It is the authority that decides whether a norm has been met or violated and thus the corresponding responsibility has been fulfilled or not. Some instances also can be norm-founding instances, depending on assumptions based on different ethical theories.

The category standard refers to normative standards, such as moral principles or legal norms (e.g., to respect others, avoid harm, save life, dispense justice).
These principles can be very general or very concrete and context-specific (e.g., such professional virtues as confidentiality, trustworthiness, honesty but also such personal values as efficiency or austerity). The standards depend, however, on their understanding as duty/obligation, right, or virtue. The level of moral commitment can differ according to the standards' bindingness and acceptable excuses.

Finally, the category consequences refers to a list of actions or judgments that are supposed to take place if a subject has or has not acted in a responsible way. Some consequences are external (e.g., legal punishment, economic disadvantage, social exclusion, social power) and some internal (feelings of guilt or shame, a bad conscience, or increased moral identity). Moral philosophy and applied ethics (in contrast to legal studies) have an ambiguous relationship to sanctions. While moral philosophy lengthily debates whether an action is morally wrong or right, only a few precepts discuss the consequences associated with a moral subject that does something morally wrong (Tonry 2011). The sphere of consequences is left to the social and legal domain. However, this is no reason to dismiss the whole concept of responsibility; our aim is to point out that it is possible to morally assess the actual social practice of sanctions regarding whether they are appropriate in kind and degree.

\section{Basic Conditions and Presuppositions of Different Models of Responsibility}

\section{Individual and Collective Agents}

The question of who counts as a moral agent is central to the need to clarify the plausibility of a particular constellation of responsibility. This debate can be traced back to Francis Herbert Bradley (1991 [1876]: 62-74). His "vulgar notion of responsibility" can be summarized in the insight that "responsibility implies ... a capacity for acting rationally, ... to act so that your actions can be counted on" (67). He also states that "a man ... is only responsible for what ... issues from an act of volition" (72). For Bradley, "without personal identity responsibility is sheer nonsense" (73).

Harry Frankfurt and John L. Mackie contributed to this debate by discussing the important role of choice and intention. Mackie's "straight rule" of responsibility ("an agent is responsible for all and only (its) 
intentional actions") is later modified by Peter French into responsibility based on being willing to do it (French 1991c: 129ff). For example, a physician involved in the Tuskegee syphilis case states that he did not have the intention to harm a patient by this experiment; his intention was to increase helpful knowledge for further vaccination research. Nevertheless, he can be held responsible for the effect of his action on the patient. It therefore seems plausible to choose being willing as the crucial criterion, rather than intention. This concept includes all cases where a person is willing to take some risks (e.g., harm others) and has the necessary knowledge (or could have it). Furthermore, this reformulation links retrospective and prospective meanings of responsibility.

If individuals have to fulfill specific conditions (such as being willing to commit an action and being aware of possible consequences) for ascribing responsibility, what does this imply for collectives? Some philosophers doubt that collectives can ever be seen as moral agents. For them, collectives must be seen as aggregations of individual agents (e.g., Ladd 1991 [1984]). Hannah Arendt insisted that the liability model of responsibility should not be applied to collectives: "Where all are guilty, nobody is guilty. Guilt, unlike responsibility, always singles out; it is strictly personal" (cited in Young 2011: 76). Her statement has to be seen in the context of her analysis of the Eichmann lawsuit. If we accept that Eichmann and other Nazis can "excuse" their actions by referring to collective orders they had to obey, we lose all measures to ascribe liability and force individuals to take responsibility. ${ }^{2}$ However, whether this fear justifies a general rejection of the concept of collective responsibility is questionable. Under the impression of various ecological, medical, and economical catastrophes such as the Bhopal disaster in 1984 or the BP Deepwater Horizon oil spill in 2010, the idea is implausible to ascribe responsibility for wrongdoings only to the single worker, a captain, or a CEO, while they must be explained by the interplay of various people in a system, such as a corporative or organized group.

One important argument that supports the idea of collectives as moral agents points to our intuition that

\footnotetext{
$\overline{{ }^{2} \text { Interestingly, }}$ this position bears a serious risk of clan liability the other way round: Where one is judged as guilty, the collective is acquitted.
}

sometimes the whole (a nation, a corporation) is more than just the sum of its single parts. Those social groups, parties, a state, or a corporation can be seen as moral agents if their actions are based upon an espirit de corps (Cooper 1991 [1968]: 258-259). This has to be understood as a joint commitment, and its effect cannot simply be explained by the aggregation of individual actions (French 1991b, 296). The argument gets even stronger where the members of organized groups ${ }^{3}$ have deliberatively chosen a collective action (e.g., by voting or being a voluntary member of a social group, such as a party). This group membership should be regarded as "active" commitment as Young stresses (2011: 137). ${ }^{4}$ French calls it the "corporation's internal decision structure ... as requisite redescription device that licenses the predication of corporate intentionality" (French 1991b: 298). French's definition applies not only to economical corporations but also to organized social groups, such as political parties, nongovernmental groups, and professions.

If we have good reasons to believe that an action was based on the condition of a joint commitment or a system effect that goes beyond the impact of single actors, we can identify a collective as agent and therefore also claim collective responsibility. This is even more so if collectives possess economical, structural, or political power. With the concept of active commitment and identification and the process of decision-making within a group, we can further define a relationship between individual and collective responsibility. There are cases where both the individual members and the collective can be held responsible or only single members or only the whole. Without a model of collective responsibility, important moral and political considerations in the whole

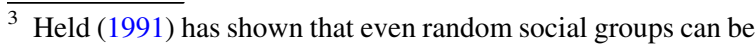
seen as collectively responsible for not doing something. This requires that the members of such a random group are aware of the moral nature of a collective action (e.g., in a situation where joining to help a single woman would protect her from rape by two strong men, while a single person cannot be expected to save her). However, in health care, all relevant social actors are rather organized groups, such as professionals (physicians, nurses), politicians, patients' advocacy groups, stakeholders.

${ }^{4}$ However, there are cases where group membership is not voluntarily chosen. For example, membership in religious, gender, or ethnic groups is often ascribed from an external point of view. In this case, the application of retrospective and prospective collective responsibility is problematic.
} 
debate on solidary health care or the role of professional associations, institutions such as hospitals or patient organizations, cannot be fully articulated.

\section{Tasks, Competence, and Capacity}

An intermediary concept that relates individual and collective responsibility is the so-called task responsibility that was introduced by Hart (1968). It relies on a socially ascribed role or relationship (e.g., a mother, a director of a company). Hence, it is important whether the agents have actively dedicated themselves to the task (e.g., as professional or in a position of an institution) or whether they find themselves in charge involuntarily (e.g., some family members).

Within collectives, we often define different tasks. These tasks imply different power-positions, decisioncompetences, and liabilities. Hart and Baier distinguish task responsibility from capacity responsibility. The latter is related to the mental and practical abilities to perform an action; diminished capacities can be seen as an excuse or justification for being less responsible. However, the distinction between task responsibility and capacity responsibility is not very helpful in cases where tasks are defined upon capacities (e.g., in cases of professional responsibilities of doctors). Instead, we suggest that by analyzing the agent, the instance, and the norms, one will also identify and differentiate the respective capacities and tasks.

Baier points to an interesting aspect: Any instance presupposes a task responsibility. An instance is an authority that has to oversee, control, and judge the responsibility of the agents. This point is important with regard to social-practical questions: If an instance has no agency power (cannot practically judge) or cannot impose sanctions, its value as a moral instance is questionable.

Thus, while individual conscience plays a crucial role for our internal process of moral deliberation and judgment, there might be cases where referring to the psychological state of a bad conscience is insufficient. For example, the phrase doctors are responsible (only) towards their own consciences (as a central statement in the German professional guidelines for doctors indicates) is very unspecific. On the one hand, it points to the fundamental requirement of moral responsibility that physicians should reflect upon their own values and cannot solely rely on social norms. On the other hand-and that would be problematic-it can be interpreted in the sense that it is sufficient if someone feels shame because something went wrong.

\section{Different Levels of Moral Standards and Their Related Sanctions}

Related to the question whether a moral agent counts as responsible is the issue of how moral responsibility is ascribed in terms of the underlying moral standards. How are the moral standards related to responsibility defined and how binding are they? This question refers to the normative complex between moral standards (norms) and sanctions. In the following, this relationship is defined in terms of proportionality: The more binding and important an underlying moral standard is the more demanding or powerful is the sanction that we would expect.

Furthermore, moral bindingness and consequences differ with regard to the temporal direction of an action: We can distinguish guilt, liability, or blame (or excuse) in retrospective cases, and precaution, prevention, or power and authority in prospective cases. In this sense, retrospective and prospective responsibility are categorically different (see above). Retrospective responsibility requires that something went bad or a consequence is assessed as morally wrong (French 1991c: 135), while prospective responsibility focuses on doing morally right or at least avoiding doing wrongs. Nevertheless, moral actions must be understood in a temporal continuum, in which backward and future-oriented views often complement each other. As discussed later, prospective responsibility of preventive health behavior can result over time in retrospective liability models if someone claims that person $\mathrm{X}$ did not sufficiently prevent a disease.

The second aspect refers to the nature (or binding character) of moral standards. Are the underlying ethical principles-for instance to respect autonomy or justice - seen as strict moral obligations, as prima facie norms, or even as virtues? Generally, strict or prima facie rules rank higher than virtues. If this is the case, it should also have consequences for our understanding of responsibility: The sanctions for violating strict rules should be seen as more demanding than for failing virtues. By this standard, a core problem of the various models of responsibilities can be addressed: How well founded and binding are the underlying norms? And if they are well founded and binding, is the assumed instance the correct one to proof and 
implement sanctions? In the case of the liability model of responsibility, we often assume that a court is the instance to clarify guilt. But on closer examination, various instances can be considered: the conscience, the profession, the family, or the broader society.

This conceptual variety illustrates one aspect of responsibility in comparison with other moral approaches prominent in applied ethics that we understand as a strength and advantage: The analysis of explicit notions of responsibility allows and requires a stringent analysis of the relationship between actors and their tasks and capacities, the underlying moral standards and their validity and binding character, as well as the instance and its power. This is especially necessary for applied and concrete contexts. Hence, being responsible can be defined in terms of duty, obligation, or right or virtue-depending on the context, but always in relation to an agent, an instance, and the sanctions we have in mind. While responsibility as such is a relational term, other moral concepts, such as duty or rights, can be seen as entitlements to treat or to be treated in a particular way. However, especially in modern, complex societies, they cannot define the whole social, relational context of application and consequences. Therefore, we argue that the proper use of "responsibility" always requires a thorough definition of the relata.

\section{The Rise and Coexistence of Different Models of Responsibility in Bioethics}

Within bioethics, the term "responsibility" has its own particular evolution. Dating the emergence of this field (dealing not only with clinical dilemmas but also with societal risks of life science research) back to the late 1960s, we see that "responsibility" was a leading term. Since then, its use and meaning(s) went manifold paths, often overlapping each other. In the following section, we summarize this evolution by pointing to three paradigms. ${ }^{5}$ We do not claim a strict historical

\footnotetext{
${ }^{5}$ While our approach is based on the aforementioned formal understandings of responsibility, Turoldo and Barilan (2007) focus on versions of professional responsibility of scholars, scientists, and physicians, distinguishing between contextspecific, antecedent, and humanized global responsibility (see also Turoldo 2009).
}

model of distinct stages, but different discursive moments of dominance. ${ }^{6}$

The first phase was dominated by discourses of collective forward-oriented responsibility, often directed toward next generations, human kind in general, and nature as such. Prominent and influential advocates were Hans Jonas or Van Rensselaer Potter who both expressed their moral concerns about technology development and increasing ecological crisis. In this context, the Asilomar Conference on recombinant DNA molecules and its risks of biohazard (Berg et al. 1975) is noteworthy. Its impact on the wider public discussion of bioethics beyond the medical-clinical context should not be underestimated. It concerns the collective (but professional) responsibility with regard to mankind and nature. Interestingly, the model of genetic responsibility, used more recently as a term for biopolitical impacts on individual life style (Lemke 2006), was coined by Lipkin and Rowley (1974) in the early 1970s to argue in favor of reproductive and positive-eugenic considerations for collective responsibility.

The second stage, in the mid-1970s, sees the intensified discussion of professional responsibility towards individuals. The Belmont Report of 1976 (US Department of Health), often considered a new touchstone for informed consent procedures and the legal protection of human research participants, also defined new, very precise responsibilities for researchers. $^{7}$

The Belmont Report (as a reaction to the Tuskegee study scandal) and the success of its theoretical extension by Beauchamp and Childress in 1979 contributed to an understanding of professional ethos based upon balancing various ethical principles: respecting patients' autonomy, beneficence, nonmaleficence, and justice. Both approaches refer in a subtle and implicit way to the professional ethos of physicians. Of course, the authors use the term "responsibility" in various constellations, such as

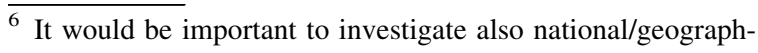
ical differences between and within these stages. For example, the discussion of individual responsibility started much earlier in the United States while it came up in Europe after first health care reforms in 1990s (Ter Meulen and Ruud 2008). In other important regions of the world, such as India, an intense bioethical discussion about professional ethics has just started (Tandon 2005; Srinivasan and Loff 2006).

7 See http://ohsr.od.nih.gov/guidelines/belmont.html
} 
"individual responsibility," "financial responsibility," "collective responsibility," "community responsibility," but never explain the meaning nor reflect the different models and their interrelations (Beauchamp and Childress 2009: 33, 48, 83, 122, 157, 249).

The perception of professional responsibility still dominates, especially when linked to legal discussions of the dos and don'ts of doctors and nurses. In our regular teaching of medical ethics, for instance, we notice that for students professional responsibility is synonym for being a good doctor. This popular usage is backed by such influential organizations as the World Medical Association, which explains in an ethical manual: "Whereas in traditional medical ethics the sole responsibility of physicians was to their individual patients, nowadays it is generally agreed that physicians should also consider the needs of society, for example, in allocating scarce healthcare resources" (Williams 2009: 22). However, professional responsibility was not only an explicit model in medical contexts, but also in other areas such as technology assessment (e.g., Ropohl 1996; Strydom 1999).

Professional responsibility can be understood as a backward model of liability, but also as a futureoriented model of guidance. With regard to the more reflective, forward character of professional responsibility, suggestions made by Turoldo (2009) can be cited. He understands his account of ethics of responsibility as a more context-sensitive approach for professional moral reasoning, which takes into account charges and potential social consequences in the treatment and communication with patients.

A third stadium, starting in the 1990s, deals with the interrelation between social and individual responsibility. This debate can be explained by two factors: First, bioethics reacts to political reforms in which public welfare and health care systems are cut back so that the tasks and burdens of the individual citizen are redefined. There arose an "increase of individual responsibility .... (as) an explicit purpose of the introduction of market forces in European health care systems" (Meulen and Ruud 2008: 192). According to the political philosopher Iris Young (2011), "a key term helping to propel welfare reform in the United States in the 1990s, as well as in some other reforming states" was "personal responsibility" (10). She refers to Schmitz who criticizes that, "it emphasizes that the responsibility you have is for yourself and your family.
... Each must self-sufficiently bear the costs of its choices, and has no moral right to expect help from others, even if the individual or the family should suffer harm or disadvantages" (Young 2011: 10). Young's conclusion even goes beyond the analysis of some public health scholars. For her, the emergence of personal responsibility has an "absolving function""to pin responsibility on one agent and to absolve others" (11). According to Ter Meulen and Jotterand (2008), personal responsibility is more a policy to control costs, but in such mid-European countries as the Netherlands, Germany, or the United Kingdom, the "government keeps monitoring accessibility and quality of care. Individualization and free choice are limited by the principles of solidarity and equity" (195). They contrast this interpretation to the health care system in the United States where the strong tradition of individualism prevails (196) and also argue that personal responsibility does not sufficiently result in free choice and autonomous decisions of the health care consumer.

Second, internal theoretical critiques concerning the "perversion of autonomy" (Gaylin and Jennings 1996) in bioethics arose, introducing moral responsibility as an opponent for too much autonomy. Thus, communitarian and feminist scholars criticized the dominant liberal paradigm of autonomy that trumps all other ethical values (Callahan 1994; Held 2006; Scully 2008). For instance, Gauthier (2002) suggests the concept of personal responsibility as a virtue "that strikes a balance between the individual and the community, between rights and obligations" (276) and emphasizes the "relationship with and obligation to others" (ibid.). Patients should include the consequences for their families and the community in their deliberations about health care choices, and also the question of who bears the costs. Gauthier's considerations are, however, very general, being unspecific with regard to different moral objects, possible instances, and even sanctions. In this sense, this approach tends to use the concept of moral responsibility again as a general place holder for being a moral person. Such a generalization runs the risk of arbitrariness or ending as rhetoric, leading to an unjustified shallowness in the use of the term (see above).

The dilemma between social and individual responsibility added another point of view, especially the controversial character of knowledge and risk 
assessment. Yoder (2002) summarizes recent ambiguities of individual responsibility, especially with regard to the increasing amount of information about healthy life styles. He concludes: "We are told how to improve our health or reduce our risk of illness by eating properly, exercising regularly, or taking aspirin daily. While this information empowers us, it also burdens us. If we can control our health, we can [be] blamed for being ill" (23). Yoder thus identifies an existing trend, already described 20 years earlier (Veatch 1980). For Veatch, health care choices and technical opportunities bear the risk that disease and disabilities are seen as someone's fault because individuals, parents, or the state have omitted to do something against the risk.

For Yoder, the crucial and problematic aspect of dealing with responsibility is that information and risks-the epistemic part of assessing consequences and agency-are too often seen as a matter of objectives facts. Instead, he pleads for a more pragmatic perspective: First, we have to acknowledge that there are limits in our knowledge of outcomes and also limits in causal explanations. Second, we have to acknowledge power distributions and how they shape our perception and construction of responsibilities. While Yoder does not reject the model of individual responsibility in general, he argues that too often the underlying values, as well as the consequences, are assumed without further deliberation. Therefore, his pragmatist-oriented suggestion is a move into the public realm for the purpose of having more public deliberations about the contribution and constitution of different kinds of moral responsibility (Yoder 2002: 30).

\section{Responsibility as Tool for Analyzing Bioethical Dilemmas}

Even the historical sketch of the evolution of responsibility in the bioethical debate already reveals a deep discrepancy: On the one hand, the word is highly relevant in public and academic debates, but on the other hand, its meaning and implications are quite often far from being self-evident, or are even controversial.

To provide a solution to this problem, two of many practical considerations are relevant: explication and pluralization. Explication means that the use of "responsibility" needs to specify the norms and instances. As we will show, claims concerning responsibility are often based on unclear or conflicting norms, such as particular professional virtues or universal moral principles. Also a wide range of instances is conceivable, but not always explicitly addressed, from individual conscience to state authorities. With pluralization, we demand that the roles and responsibilities of the different agents involved in moral conflicts are taken into consideration. The formula developed above provides a tool to analyze the meaning and role of responsibility in particular practical contexts. The juxtaposition of different forms and levels should bring out what is predominant in the one context and perhaps missing in the other. In the subsequent section, we choose three prominent cases of moral responsibility which illustrate the purpose of our tool.

The first case refers to organ transplantation. Here, professional responsibilities are becoming more complex as doctors acquire additional tasks and functions. On the one hand, the individual patient is still often perceived as the central object of the physician's prospective responsibility. The underlying standards are traditional professional virtues of care and beneficence. They require that the doctor dedicates his or her efforts to this single patient's survival and wellbeing for the time of treatment (Tauber 2005). On the other hand, in the understanding of organs as scarce resources, the physician also increasingly functions as a gate keeper. $\mathrm{He}$ or she adopts the prospective responsibility to ensure fair and efficient allocation of organs over a virtually unlimited space of time. This practice can lead to conflicts on the level of standards and objects. The new distributive responsibility is defined by temporal dimensions and public health norms of efficiency and justice that are often not part of doctors' traditional professional competence. It also requires doctors to distance themselves from the individual needy person and the concrete setting of treatment. They now have to envisage the collective of potential recipients as the object of their responsibility. This may also involve the task to evaluate, compare, and weigh several persons' life expectancies and quality of life against each other from an impartial point of view. Such a conflict of responsibilities is, however, easily neglected because the discussion of doctors' professional responsibilities is still mainly confined to the individual doctor-patient relationship. 
Table 1 Summary of 7 major relata for professional responsibility in organ transplantation

\begin{tabular}{|c|c|c|c|c|c|c|}
\hline $\begin{array}{l}\text { Subject } \\
\text { (in different } \\
\text { roles) }\end{array}$ & $\begin{array}{l}\text { Object (seen as } \\
\text { morally relevant) }\end{array}$ & $\begin{array}{l}\text { Instance } \\
\text { (norm- } \\
\text { proofing) }\end{array}$ & $\begin{array}{l}\text { Moral- } \\
\text { relevant } \\
\text { standard }\end{array}$ & Temporal direction & Consequences & Time frame \\
\hline \multirow[t]{4}{*}{ Physician } & \multirow[t]{2}{*}{ Patient (recipient) } & \multirow[t]{4}{*}{ Law/ethos } & \multirow[t]{2}{*}{ Beneficence } & Retrospective_negative & $\begin{array}{r}\text { Professional } \\
\text { sanctions? }\end{array}$ & \multirow{2}{*}{$\begin{array}{l}\text { Limited to } \\
\text { individual } \\
\text { treatment until } \\
\text { cure or death }\end{array}$} \\
\hline & & & & Prospective_positive & $\begin{array}{c}\text { Recognition } \\
\text { by patient }\end{array}$ & \\
\hline & \multirow[t]{2}{*}{$\begin{array}{l}\text { Collective of } \\
\text { recipients }\end{array}$} & & \multirow[t]{2}{*}{$\begin{array}{l}\text { Justice/ } \\
\text { efficiency? }\end{array}$} & Retrospective_negative & $\begin{array}{l}\text { Legal } \\
\text { sanctions }\end{array}$ & \multirow{2}{*}{$\begin{array}{l}\text { Theoretically } \\
\text { unlimited (as long } \\
\text { as there are not } \\
\text { enough donor } \\
\text { organs) }\end{array}$} \\
\hline & & & & Prospective_positive & $\begin{array}{l}\text { Power as gate } \\
\text { keeper }\end{array}$ & \\
\hline
\end{tabular}

Interestingly, sanctions in the individual and collective area are located on different levels of severity. While failure to meet the traditional responsibility of beneficence primarily results in professional sanctions, arbitrary discrimination regarding access to the waiting list will be tried in front of court and be punished according to criminal law (see Table 1 for summary).

The second example is concerned with responsibilities emerging in the context of advance directives (ADs). The mere legal possibility to lay down one's preferences, as it is now common in many Western countries, aims at ensuring patient's autonomy and self-determined death. At the same time it also creates a responsibility to take care of oneself, thus avoiding the prospective negative consequences of depending on the decisions of others. Additionally, ADs affect close relatives as objects of responsibility. Surviving family members are relieved from the insecurity involved in making advocatory decisions over life and death and thus are "spared the agony of not knowing what the patient would have wanted" (Gauthier 2002: 279).

However, deriving from this a "moral responsibility of each member of the community to make their wishes regarding end-of-life treatment known in advance" (ibid.) does not do justice to the complexity of the new situation. The patient's relatives also find themselves to be subjects of responsibilities. They have acquired the prospective moral (sometimes even legal) responsibility of ensuring that the incompetent patient's living will is interpreted and executed correctly. The underlying norm of this responsibility is respect for autonomy. If the relatives fail to meet the norm, they can lose their decision power. Therefore, it is inappropriate to understand the individual as the sole subject and the relatives only as the object of responsibility. The responsibilities are mutual and the normative standards - the principle of personal autonomy on the one hand, the virtue of being considerate regarding potential psychological distress on the other-have to be juxtaposed in order to assess their relative weight. A thorough analysis of responsibilities allows an understanding of the complexity of different moral subjects and norms involved, even within one family (see Table 2 for summary).

The third case refers to responsibility in the context of genetic testing. Here, the term "genetic responsibility" has gained popularity. In contrast to its initial meaning (see above), it is now used to describe and criticize a process of geneticization of the identity of patients and their families but also of healthy persons (e.g., Novas and Rose 2000; Lemke 2006). This knowledge of being at genetic risk means that "individuals and families have a right, a duty, even a compulsion, to choose in relation to managing the risk of themselves and others" (Arribas-Ayllon et al. 2011: 5).

The preventing-risk paradigm underlying this model must be primarily understood as a prospective responsibility. Reflecting upon the risk to manifest an inheritable disease, different proactive actions appear possible: family planning, or in the case of such a treatable disease as cancer, to adopt a healthy lifestyle (Raz and Schicktanz 2009). However, the underlying norms vary. Within the choice-paradigm, autonomy as a norm would mean that genetic testing allows individuals to choose freely (to be tested or not, to prevent or not). The negative consequence based on a strict autonomy-norm would then be to accept if such a disease occurs. 
Table 2 Individual and family responsibility in the context of advance directives

\begin{tabular}{|c|c|c|c|c|c|c|}
\hline $\begin{array}{l}\text { Subject } \\
\text { (in different } \\
\text { roles) }\end{array}$ & $\begin{array}{l}\text { Object } \\
\text { (seen as } \\
\text { morally } \\
\text { relevant) }\end{array}$ & $\begin{array}{l}\text { Instance } \\
\text { (norm- } \\
\text { proofing) }\end{array}$ & $\begin{array}{l}\text { Moral- } \\
\text { relevant } \\
\text { standard }\end{array}$ & Temporal direction & Consequences & Time frame \\
\hline \multirow[t]{2}{*}{$\begin{array}{l}\text { Citizens as } \\
\text { potential } \\
\text { patient }\end{array}$} & Self & Conscience & $\begin{array}{l}\text { Virtue: to be } \\
\text { considerate }\end{array}$ & Retrospective_negative & $\begin{array}{l}\text { Dependency (on } \\
\text { physician and } \\
\text { family) if no } \mathrm{AD} \text {, } \\
\text { or even blame }\end{array}$ & $\begin{array}{l}\text { For the time of being } \\
\text { competent, but } \\
\text { disputable how long in } \\
\text { advance is valid }\end{array}$ \\
\hline & Relatives & & & Prospective_positive & $\begin{array}{l}\text { Self-determined end } \\
\text { of life }\end{array}$ & \\
\hline Family & Patient & $\begin{array}{l}\text { Law (as } \\
\text { attorney) }\end{array}$ & $\begin{array}{l}\text { Respect for } \\
\text { autonomy/ } \\
\text { care }\end{array}$ & Prospective_negative & $\begin{array}{l}\text { Only in life-ending } \\
\text { cases: loss of } \\
\text { decision power (to } \\
\text { court) }\end{array}$ & $\begin{array}{l}\text { In case of patient's loss } \\
\text { of competence }\end{array}$ \\
\hline
\end{tabular}

If autonomy is also understood as freedom to know or not to know, no one else has the right to judge or guide individual decisions. Therefore, suggestions in the realm of prevention strengthening the causal and practical need for genetic knowledge to shape preventive campaigns and preventive medicine often tacitly replace the norm autonomy by the norm of selfcare (Smith et al. 2005). Such self-care allows a preventive forward-directed individual responsibility. This is an understanding that people nowadays share. For instance, the user of an internet forum commenting on the direct-to-consumer genetics offered by 23andMe states: "Just got my 23andMe results back! Glad I can be proactive on delaying or preventing some of these conditions that I'm prone to" (http:// twitter.com/\#!/23andMe/favorites/11.7.2011). However, this can easily turn into a liability model. This is exactly the ambiguity of individual responsibility with regard to health prevention that Yoder pointed out. Liability in a strong sense would mean that individuals are blamed for being not preventive or careful enough. This is discussed in cases like obesity, a condition where genetic as well as life style factors interact (Hilbert 2008).

Moreover, genetic responsibility often does not differentiate between the individual's responsibility toward himself and the one toward his family. This is problematic. As Arribas-Ayllon et al. (2008) reveal in their interview study, about genetic testing the majority of individuals as family members practiced nondisclosure: "The prospect of disclosure was expressed as a practical moral burden of calculating who to tell and when to tell them. ...." (11). They justified nondisclosure in terms of their own guilt, the possibility of incurring blame or by pre-empting a relative's right not to know. One of the most common explanations for not disclosing intergenerationally was the strong desire to protect the future autonomy of children and young adults. Therefore, the authors argue "for a different sense of genetic responsibility, which is neither reducible to transcendental communication nor that of rational autonomy" (20). They instead suggest "that people resist the onerous obligation of managing genetic risk and disclosing bad news to kin to escape the moral/ discursive confinement of autonomy" (19). They interpret this as an intensity of affect (ibid.), a prediscursive strategy of these family members practicing nondisclosure.

However, we take more seriously what their informants gave as reasons. Here, norms such as respecting the right not to know, and care for family members to avoid socio-psychological burdens for others and the family as whole were mentioned. According to our analysis, those who disclose genetic knowledge to family members do not subsequently act upon autonomy as the leading norm; rather, they act on the norm that others have a right to know or in the case of nondisclosure a right not to know. Within the ethics of genetics, these norms are intensively discussed and are also part of legal-political debates (Chadwick 2009). Therefore, different kinds of consequences can result. Blame as well as feelings of guilt are feared by family members, in both liability models. Longlasting distress within a family can result if the persons involved favor different norms. 
Furthermore, positive-prospective consequences vary, too. In the case of following the norm right to know/duty to inform, this choice results in relying on a genetic paradigm of risk prevention and therefore proactive health behavior for many years, even lifelong. In contrast, following the norm not to know will yield prospective consequences to master a harmonic family life, often based on the task responsibility to take the power of decisions, as parents do for their children, often directly after the counseling process (Hildt 2009).

As we already see, the meaning and interpretation of genetic responsibility is diverse, even contradictory. This ambiguity can be avoided by being more precise, detailed, and explicit about who is responsible toward whom on the basis of which norm, proofed by which instance, and with which consequences. As the case of individual and family responsibility also reveals, we have to reflect upon such concepts as conscience and family communication to understand the loci of everyday moral dilemmas of genetic counseling.

Moreover, the case of genetic testing shows that not only individuals and their families are involved, but also professionals. Professional responsibility is often understood in terms of nondirective counseling during treatment. However, the conflicts and concerns that individuals as well as family members express invite us to question whether the concept of nondirective counseling is always appropriate and justified (Raz and Atar 2003) (see Table 3 as summary).

While it is assumed it is the best standard to be consistent to the norm of autonomy, it can easily conflict over time with the norm right to know of

Table 3 Summary of the major 7 relata for individual, family, professional, and social responsibility in the case of genetic testing

\begin{tabular}{|c|c|c|c|c|c|c|}
\hline $\begin{array}{l}\text { Subject (in } \\
\text { different } \\
\text { roles) }\end{array}$ & $\begin{array}{l}\text { Object } \\
\text { (seen as } \\
\text { morally } \\
\text { relevant) }\end{array}$ & $\begin{array}{l}\text { Instance } \\
\text { (norm- } \\
\text { proofing) }\end{array}$ & $\begin{array}{l}\text { Moral- } \\
\text { relevant } \\
\text { standard }\end{array}$ & Temporal direction & Consequences & Time frame \\
\hline \multirow[t]{6}{*}{ Self } & \multirow[t]{3}{*}{ Self } & \multirow[t]{3}{*}{ Conscience } & \multirow[t]{2}{*}{ Autonomy } & Retrospective_negative & $\begin{array}{l}\text { Accept possible } \\
\text { harm }\end{array}$ & \multirow[t]{2}{*}{$\begin{array}{l}\text { In late onset disease: life } \\
\text { long, decades }\end{array}$} \\
\hline & & & & Prospective_positive & Free choice & \\
\hline & & & Self-care & $\begin{array}{l}\text { Retrospective_negative } \\
\text { Prospective_positive }\end{array}$ & $\begin{array}{l}\text { Guilt/blame } \\
\text { Prevention }\end{array}$ & $\begin{array}{l}\text { In late onset disease: life } \\
\text { long, decades }\end{array}$ \\
\hline & \multirow[t]{3}{*}{ Family } & \multirow[t]{3}{*}{ Conscience } & $\begin{array}{l}\text { Right to } \\
\text { know/duty } \\
\text { to inform }\end{array}$ & Retrospective_negative & $\begin{array}{l}\text { Blame/guilt if not } \\
\text { informed } \\
\text { Preventive (e.g., } \\
\text { family planning), } \\
\text { good "risk" } \\
\text { management }\end{array}$ & $\begin{array}{l}\text { Closely after the } \\
\text { knowledge is gained, } \\
\text { but theoretical for } \\
\text { many years }\end{array}$ \\
\hline & & & \multirow{2}{*}{$\begin{array}{l}\text { Right not to } \\
\text { know/duty } \\
\text { not to tell }\end{array}$} & Retrospective_negative & $\begin{array}{l}\text { Family distress if } \\
\text { told }\end{array}$ & \multirow{2}{*}{$\begin{array}{l}\text { Closely after the } \\
\text { knowledge is gained, } \\
\text { but theoretical for } \\
\text { many years }\end{array}$} \\
\hline & & & & Prospective_positive & $\begin{array}{l}\text { Protection of } \\
\text { families from } \\
\text { social- } \\
\text { psychological } \\
\text { burdens }\end{array}$ & \\
\hline \multirow[t]{2}{*}{ Professional } & \multirow[t]{2}{*}{ Patient } & \multirow[t]{2}{*}{$\begin{array}{l}\text { Soft law/ } \\
\text { law }\end{array}$} & \multirow{2}{*}{$\begin{array}{l}\text { Non- } \\
\text { directive } \\
\text { counseling }\end{array}$} & Retrospective_negative & $\begin{array}{l}\text { Legal liability for } \\
\text { counselor }\end{array}$ & \multirow[t]{2}{*}{ During the treatment } \\
\hline & & & & Prospective_positive & $\begin{array}{l}\text { Professional } \\
\text { exclusiveness } \\
\text { (power) }\end{array}$ & \\
\hline \multirow[t]{2}{*}{$\begin{array}{l}\text { Public } \\
\text { healthcare } \\
\text { system }\end{array}$} & \multirow[t]{2}{*}{ Citizens } & \multirow[t]{2}{*}{$?$} & \multirow[t]{2}{*}{$\begin{array}{l}\text { Justice and } \\
\text { equality }\end{array}$} & Prospective_negative & $\begin{array}{l}\text { Waste of health care } \\
\text { resources/ } \\
\text { inefficient } \\
\text { allocation }\end{array}$ & \multirow[t]{2}{*}{$\begin{array}{l}\text { Theoretically decades, } \\
\text { but changing political } \\
\text { systems }\end{array}$} \\
\hline & & & & $?$ & $?$ & \\
\hline
\end{tabular}


family members. If we even assume there are preventive measures that are really easy, harmless, and cheap to apply, nondirective counseling can be questioned from a social responsibility point of view. The latter wants to ensure just and fair allocation of financial resources to all potential patients. However, when dealing with responsibility in a case that involves a collective - such as a society or nationwe need more clearness about what is the appropriate instance to judge and evaluate norms and consequences. We also need to know how to deal with longterm effects in a political system of changing parties and power relations. Hence, political-philosophical considerations that seek to solve the problem by procedural, political, or expertocratic solutions might help (Yoder 2002).

The aim of the three cases was to illustrate the application of the responsibility-formula-tool to structure bioethical as well as socio-empirical insights. This approach allows a comparison, detection of inconsistencies, and analysis of implicit or even conflicting normative relata. A next stage is the explication and increase of consistency in justification. None of these analyses claims to be sufficient for the fields of application. Complexity will increase with the number of relata to be considered. With regard to restriction in each of these areas, it will be necessary to detect and analyze the complexity within each of these fields.

\section{Conclusions}

"Responsibility" is a concept commonly and prominently used in academic, political, and public discourses on bioethical questions, but mostly in an underdetermined, ambiguous, or even ideologically instrumentalized way. Therefore, its analysis constitutes an important step toward a clarification of these discourses and a critical reflection of the claims made. In this sense, bioethics does not only deal with moral problems in medical-clinical settings, it also constantly includes reflection about the tools and conceptions scholars use.

Our considerations want to contribute to this reflection, taking real-world needs into account. Various concepts of responsibility can be found in empirical contexts and even lay notions, sometimes in a coherent, sometimes in an incoherent way. These real-world problems need an ethical language suitable to face, understand, and deal with social connectivity and complexity.

In the perspective of responsibility, the use of other meta-ethical conceptions of duties, rights, or virtues can be integrated into a broad action-theoretical framework that forces us to consider the subject-object relationship, time, instances, and consequences. This perspective also allows us to cross-section differences between deontological and utilitarian approaches that sometimes dominate moral philosophical debates. Furthermore, the proposed formula of responsibility also bridges deductive (top-down) and inductive (bottom-up) approaches as it invites into a discourse about the identification, determination, and interrelation between subjects and objects.

"Responsibility" is not a normative concept that replaces ethical principles such as autonomy, beneficence, justice, nor does it supersede them. Without denying the importance of personal autonomy for bioethics and clinical practice, however, responsibility can help to complement the bioethical debate by highlighting the normative points of view of other actors, social groups, and society as a whole.

It should have become clear that "responsibility" goes beyond the debate of middle-range principles in which many dilemmas are only understood and conceptualized as conflicts between competing ethical principles. This might be still true for many cases. However, our analysis of responsibility as a tool illustrates that the structure and context of moral dilemmas in particular fields can (sometimes additionally or also exclusively) rely on many variables, including competing subjects, objects, consequences aimed for, and instances. Further research has to show that the suggested tool can contribute systematically to the resolution of conflicts and dilemmas based on insufficient, implicit, or inappropriate ascriptions of responsibility.

Acknowledgments The authors would like to thank Aviad Raz (Be'er Sheva, IL) for instructive comments and Richard M. Crum (Edmond, USA) for help with language. The work of Silke Schicktanz was conducted within the framework of the project "Cross-cultural Ethics of Health and Responsibility. Expert and Lay Perspectives Regarding Bioethical Dilemmas in Germany and Israel," funded by the German-Israeli-Foundation (Grant No. 1023-317.4/2008). The work of Mark Schweda was conducted within the framework of the project "Biomedical Life-Plans for Aging. Values Between Individual Ethical Reflection and Social Standardization," funded by the German Federal Ministry for Education and Research (Grant No. 01GP1004A). 
Open Access This article is distributed under the terms of the Creative Commons Attribution Noncommercial License which permits any noncommercial use, distribution, and reproduction in any medium, provided the original author(s) and source are credited.

\section{References}

Arribas-Ayllon, Michael, Srikant Sarangi, and Angus Clarke. 2008. Managing self-responsibility through other-oriented blame: Family accounts of genetic testing. Social Science and Medicine 66: 1521-1532.

Arribas-Ayllon, Michael, Katie Featherstone, and Paul Atkinson. 2011. The practical ethics of genetic responsibility: Non-disclosure and the autonomy of affect. Social Theory \& Health 9: 3-23.

Baier, Kurt. 1991. Types of responsibility. In The spectrum of responsibility, ed. Peter A. French, 117-122. New York: St. Martins Press.

Bayertz, Kurt. 1995. Eine kurze Geschichte der Herkunft der Verantwortung. In Verantwortung. Prinzip oder problem?, ed. Kurt Bayertz, 1-72. Darmstadt: Wissenschaftliche Buchgesellschaft.

Beauchamp, Tom L., and James F. Childress. 2009. Principles of biomedical ethics (6th ed). Oxford: Oxford University Press.

Berg, Paul, David Baltimore, Sydney Brenner, R.O. Robin III, and Maxine Singer. 1975. Asilomar conference on recombinant DNA molecules. Science 188: 991-995.

Bradley, Francis Herbert. 1991. The vulgar notion of responsibility. In The spectrum of responsibility, ed. Peter A. French, 62-74. New York: St Martins Press.

Bundesärztekammer. 2011. Grundsätze der Bundesärztekammer zur ärztlichen Sterbebegleitung. Deutsches Ärzteblatt 108: 346-348.

Callahan, Daniel. 1994. Bioethics: Private choice and common good. The Hastings Center Report 24: 28-31.

Callahan, Daniel, Peter Singer, and Ruth Chadwick (eds.). 1997. Encyclopedia of applied ethics. San Diego: Academic Press.

Center for Medicare and Medicaid Services. 2006. Roadmap to medicaid reform: New options to improve and expand insurance coverage for acute care needs. https://www.cms. gov/smdl/downloads/Rvltcneeds.pdf. Accessed on 1 Nov 2011

Chadwick, Ruth. 2009. The right to know and the right not to know. Ten years on. In Disclosure dilemmas. Ethics of genetic prognosis after the "right to know/not to know" debate, ed. Christoph Rehmann-Sutter, and Hansjakob Müller, 9-18. Farnham: Ashgate Publishing Company.

Cooper, David E. 1991. Collective responsibility. In The spectrum of responsibility, ed. Peter A. French, 255-264. New York: St Martins Press.

Feinberg, Joel. 1991. The moral and legal responsibility of the bad samaritan. In The spectrum of responsibility, ed. Peter A. French, 148-169. New York: St Martins Press.

French, Peter A. (ed.). 1991a. The spectrum of responsibility. New York: St Martins Press.
French, Peter A. 1991b. The corporation as a moral person. In The spectrum of responsibility, ed. Peter A. French, 290-304. New York: St Martins Press.

French, Peter A. 1991c. Fishing the red herrings out of the sea of moral responsibility. In The spectrum of responsibility, ed. Peter A. French, 129-144. New York: St Martins Press.

French, Peter A. 1991d. Types and principles of responsibility. In The spectrum of responsibility, ed. Peter A. French, 113-116. New York: St Martins Press.

Gauthier, Candace Cummins. 2002. The virtue of moral responsibility in healthcare decisionmaking. Cambridge Quarterly of Healthcare Ethics 11: 273-281.

Gaylin, Willard, and Bruce Jennings. 1996. The perversion of autonomy. New York: Free Press.

Hart, Herbert Lionel Adolphus. 1968. Legal responsibility and excuses. In Punishment and responsibility: Essays in the philosophy of law, 28-53. Oxford: Clarendon Press.

Held, Virginia. 1991. Can a random collection of individuals be morally responsible? In The spectrum of responsibility, ed. Peter A. French, 265-274. New York: St Martins Press.

Held, Virginia. 2006. The ethics of care. Personal, political, and global. New York: Oxford University Press.

Hilbert, Anja. 2008. Adipositasprävention: Möglichkeiten und Grenzen der Eigenverantwortung. In Gewichtige gene. Adipositas zwischen Prädisposition und Eigenverantwortung, ed. Anja Hilbert, Winfried Rief, and Peter Dabrock, 29-45. Bern: Verlag Hans Huber.

Hildt, Elisabeth. 2009. Predictive genetic testing, autonomy and responsibility for future health. Medicine Studies 1: 143-153.

Holl, Jann, Hans Lenk, and Matthias Maring. 2001. Verantwortung. In Historisches Wörterbuch der Philosophie, 566-670, Basel: Schwabe.

Ladd, John. 1991. Corporativism. In The spectrum of responsibility, ed. Peter A. French, 305-312. New York: St Martins Press.

Lemke, Thomas. 2006. Genetic responsibility and neo-liberal governmentality: Medical diagnosis as moral technology. In Michel Foucault and power today. International multidisciplinary studies in the history of the present, ed. Alain Beaulieu, and David A. Gabbard, 83-91. Oxford: Lexington Books.

Lipkin, Mack Jr., and Peter T. Rowley (eds.). 1974. Genetic responsibility: On choosing our childrens' genes. New York: Plenum Press.

Novas, Carlos, and Nikolas Rose. 2000. Genetic risk and the birth of the somatic individual. Economy and Society 29: 485-513.

Raz, Aviad, and Marcela Atar. 2003. Nondirectiveness and its lay interpretations: The effect of counseling style, ethnicity and culture on attitudes towards genetic counseling among Jewish and Bedouin respondents in Israel. Journal of Genetic Counseling 12: 313-332.

Raz, Aviad, and Silke Schicktanz. 2009. Lay perceptions of genetic testing in Germany and Israel: The interplay of national culture and individual experience. New Genetics and Society 28: 401-414.

Ropohl, Günther. 1996. Ethik und Technikbewertung. Frankfurt am Main: Suhrkamp.

Scully, Jackie L. 2008. Disability bioethics: Moral bodies, moral differences. Plymouth: Rowmann \& Littlefield. 
Smith, George Davey, Sarah Ebrahim, Shah Lewis, Anna L. Hansell, Lyle J. Palmer, and Paul R. Burton. 2005. Genetic epidemiology and public health: Hope, hype, and future prospects. Lancet 366: 1484-1498.

Strydom, Piet. 1999. The challenge of responsibility for sociology. Current Sociology 47: 65-82.

Srinivasan, Sandhya, and Bebe Loff. 2006. Medical research in India. Lancet 367: 1962-1964.

Tandon, P.A. 2005. Bioethics: An emerging discipline. Indian Journal of Medical Research 121(1): 1-4.

Tauber, Alfred I. 2005. Patient autonomy and the ethics of responsibility. Cambridge: MIT Press.

Ter Meulen, Ruud, and Fabrice Jotterand. 2008. Individual responsibility and solidarity in European health care: Further down the road to two-tier system of health care. Journal of Medicine and Philosophy 33: 191-197.

Tonry, Michael (ed.). 2011. Why punish? How much? A reader on punishment. Oxford: Oxford University Press.

Turoldo, Farbrizio. 2009. Responsibility as a framework for public health interventions. American Journal of Public Health 99: 1197-1202.
Turoldo, Fabrizio, and Y. Michael Barilan. 2007. The concept of responsibility: Three stages in its evolution within bioethics. Cambridge Quarterly of Healthcare Ethics 17: 114-123.

Unesco. 2005. Universal declaration on bioethics and human rights. (Adopted by acclamation on 19 October by the 33rd session of the General Conference of UNESCO).

Veatch, Robert M. 1980. Voluntary risks to health. JAMA 43: 50-55.

Warren, Mary Anne. 2000. Moral status-obligations to persons and other living things. Oxford: Oxford University Press.

Werner, Micha H. 2002. Verantwortung. In Handbuch ethik, ed. Marcus Düwell, Christoph Hübenthal, and Micha $\mathrm{H}$. Werner, 521-527. Stuttgart: Metzler.

Williams, John R. 2009. Medical ethics manual. World Medical Assembly: Ferney-Voltaire Cedex.

Yoder, Scot D. 2002. Individual responsibility for health. Decision, not discovery. The Hastings Center Report 32: 22-31.

Young, Iris Marie. 2011. Responsibility for justice. Oxford: Oxford University Press. 